\title{
1 Data variability in standardised cell culture experiments
}

2 Ian G. Reddin, Tim Fenton, Mark N. Wass*, Martin Michaelis*

3 School of Biosciences, University of Kent, Canterbury, UK

4 * Correspondence to: m.n.wass@kent.ac.uk (M.N.W.), m.michaelis@kent.ac.uk 5 (M.M.)

6

7 


\section{Abstract}

9 Despite much debate about a perceived 'reproducibility crisis' in the life

10 sciences, it remains unclear what level of replicability is technically possible [1,2].

11 Here, we analysed the variation among drug response data of the NCI60 project,

12 which for decades has tested anti-cancer agents in a 60-cell line panel following a

13 standardised protocol [3]. In total, 2.8 million compound/cell line experiments are

14 available in the NCI60 resource CellMiner [4]. The largest fold change between the

15 lowest and highest GI50 (concentration that reduces cell viability by $50 \%$ ) in a

16 compound/cell line combination was $3.16 \times 10^{10}$. All compound/ cell line

17 combinations with $>100$ experiments displayed maximum GI50 fold changes $>5$,

$1899.7 \%$ maximum fold changes $>10,87.3 \%$ maximum fold changes $>100$, and $70.5 \%$

19 maximum fold changes $>1000$. FDA-approved drugs and experimental agents

20 displayed similar variation. The variability remained very high after removal of

21 outliers and among experiments performed in the same month. Hence, our analysis

22 shows that high variability is an intrinsic feature of experimentation in biological

23 systems, even among highly standardised experiments in a world-leading research

24 environment. Thus, a narrow focus on experiment standardisation does not ensure a

25 high level of replicability on its own.

26 


\section{Introduction}

28 In the life sciences, there is a crisis narrative and a perception of a lack of

29 data reproducibility ("reproducibility crisis" or "replication crisis") [2,5-10]. However,

30 the actual scale of the crisis remains unclear and evidence is largely anecdotal [2].

31 Much of the data are based on researcher views expressed in survey responses [11-

32 13] or provided as Comments or Correspondence without providing detailed 33 information [14,15].

34 One project that investigates the replicability of research data is the

35 'Reproducibility Project: Cancer Biology', which independently repeats influential 36 preclinical studies (https://elifesciences.org/collections/9b1e83d1/reproducibility-

37 project-cancer-biology). So far, 17 replication studies have been completed. Five 38 studies reported the successful reproduction of the original studies [16-20], while 39 eight reported a mixed outcome [21-28], and four failed to reproduce the original 40 findings [29-32]. It is not clear whether these data are representative. It is a small

41 dataset focused on small, early, and highly cited studies, which are more likely to 42 overestimate effects [33].

43 There is also a lack of agreement on the expected level of data replicability

44 [1]. In a dispute about the consistency of two large pharmacogenomic screens in 45 cancer cell line panels, the Genomics of Drug Sensitivity in Cancer database and the 46 Cancer Cell Line Encyclopedia [34-37], four analyses by different groups concluded 47 a reasonable level of consistency [37-40], while six studies, all by the same group, 48 disagreed [36,41-45].

49 To develop a realistic understanding of the replicability of standardised assays

50 in a world-leading research environment, we investigated the variation in drug 51 response data from the NCI60 screen [3]. Since 1985, the NCI60 screen has tested 
52 the anti-cancer activity of thousands of compounds multiple times in a 60 -cell line

53 panel following strict standard operating procedures (Figure 1A) [3,4,47-51]. Thus,

54 the $\mathrm{NCl} 60$ database provides an unprecedented wealth of data on the replicability of

55 findings using highly standardised procedures by highly skilled experts.

56

57 


\section{Results}

\section{NCl60 drug response data are characterised by a high level of variability}

All drug sensitivity data derived from NCI60 testing are made available via

61 Cell Miner [4,47,48,50,51]. In total, 52,585 compounds were tested in the NCI60

62 resulting in $2.8 \times 10^{6}$ compound/cell line combinations. Two or more (up to 2,286 )

63 experiments were carried out for 11,841 compounds and 594,450 compound/cell line

64 combinations (Figure 1B, Extended Data Table 1; Extended Data Table 2). More

65 than 100 experiments in at least one cell line were performed for 18 compounds and

66 more than 1,000 experiments for two compounds (Extended Data Table 3).

67 Concentration ranges varied from $10^{1.2}$ to $10^{12.1} .612$ compounds were screened with

68 multiple concentration ranges, and the most common concentration range was $10^{4}$

$69(11,213 / 94.7 \%$ of the compounds), representing the standard testing range using

70 five 10-fold dilution steps (Extended Data Table 4).

71 The maximum fold change between the lowest and highest GI50

72 concentration (reduces cell viability by $50 \%$ ) was detected for

73 cyanomorpholinodoxorubicin in the colorectal cancer cell line COLO 205 (3.16 x

$74 \mathrm{10}^{10}$ ) (Extended Data Figure 1A, Extended Data Table 5). 232,315 (39.1\%) drug/cell

75 line combinations displayed maximum fold changes $>2,108,247$ (18.2\%) drug/cell

76 line combinations fold changes $>5,59,638$ (10\%) drug/cell line combinations fold

77 changes $>10,19,089(3.2 \%)$ drug/cell line combinations $>100$, and $8320(1.4 \%)$

78 drug/cell line combinations $>1,000$ (Extended Data Table 5).

79

80 Variability increases with the number of experiments

81 The percentage of compound/cell line combinations with high maximum fold

82 change strongly increased with the number of experiments (Figure 1C, Extended 
83 Data Figure 2A, Extended Data Figure 2B, Extended Data Table 6). The mean and

84 median GI50 fold changes increased from 41,292 and 1.4 for compound/cell line

85 combinations with two experiments to $53,343,445$ and 1841 for compound/cell line

86 combinations with $>20$ experiments (Figure 1C, Figure 1D, Extended Data Table 6).

87 When we considered compound/cell line combinations with a minimum of five

88 experiments, 25,496 (84.4\%) of 30,212 compound/cell line combinations displayed

89 maximum fold changes $>2$ and 3,832 (12.7\%) compound/cell line combinations

$90>1000$. For compound/ cell line combinations with $>100$ experiments, $100 \%$ of 794

91 compound/ cell line combinations displayed a maximum fold change $>5$ and $70.5 \%$

92 (560 out of 794) displayed a maximum fold change $>1000$ (Figure 1E, Extended

93 Data Table 7).

94 Taken together, maximum GI50 fold changes increase with the number of

95 experiments. In agreement, a significant correlation was detected between maximum

96 Gl50 fold changes and the number of experiments per compound/cell line

97 combination (Spearman correlation coefficient $=0.34, p<2.2 \times 10^{-16}$ ) (Extended

98 Data Figure 3A).

99 


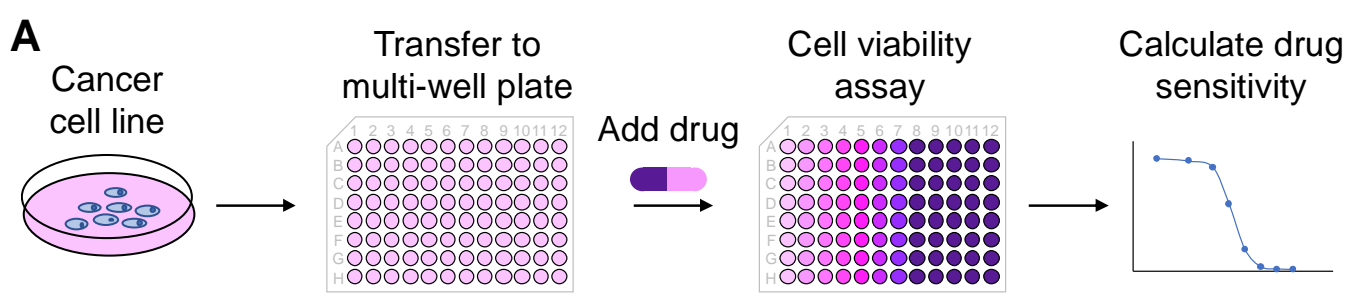

\section{B}

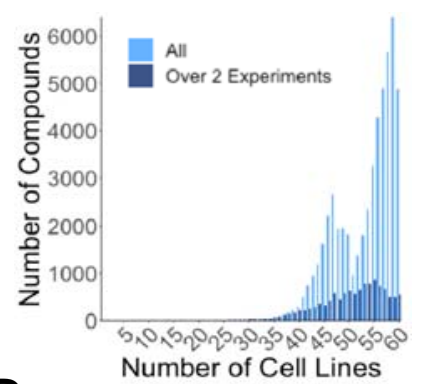

D

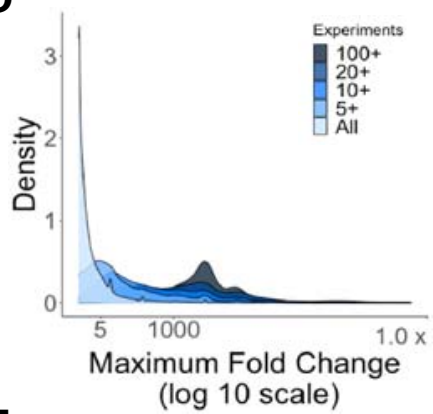

E

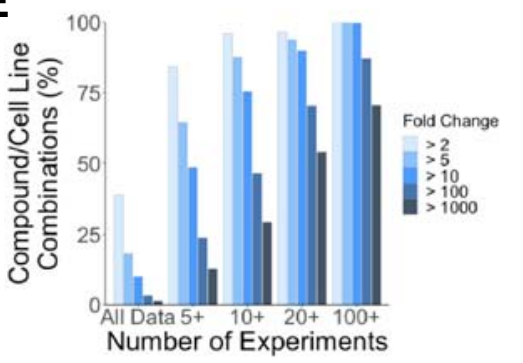

C

$\mathbf{F}$
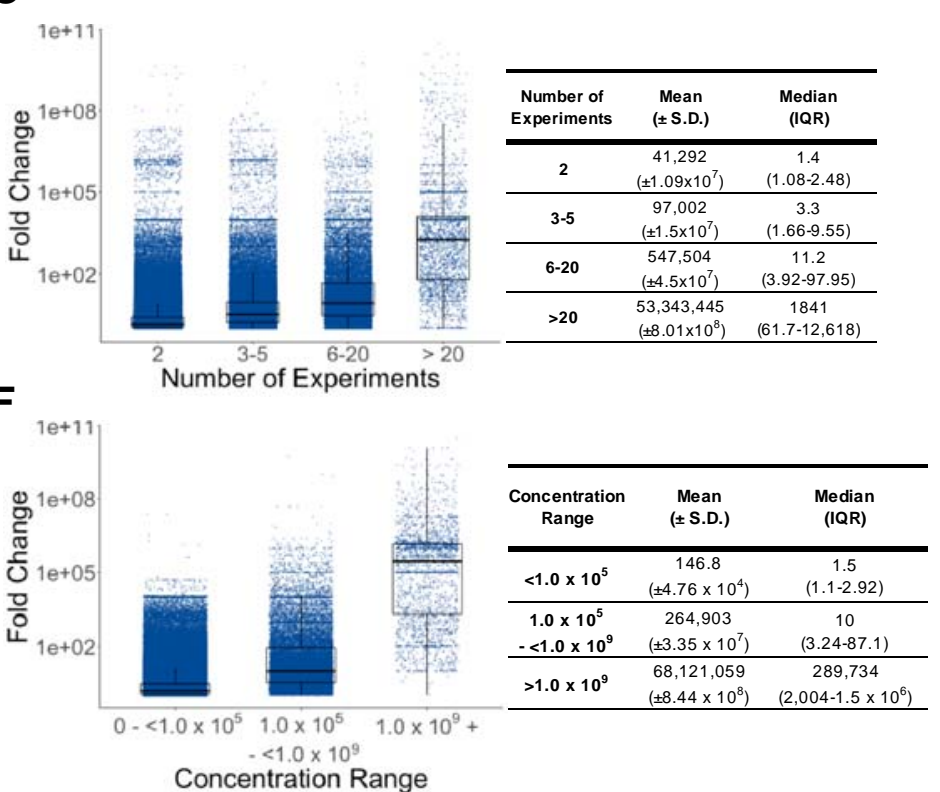

Concentration Range

\begin{tabular}{ccccccc}
\hline $\begin{array}{c}\text { Experimental } \\
\text { Group }\end{array}$ & $\begin{array}{c}\text { Number of } \\
\text { Combinations }\end{array}$ & $\mathbf{> 2}$ & $\mathbf{> 5}$ & $\mathbf{> 1 0}$ & $\mathbf{> 1 0 0}$ & $\mathbf{> 1 0 0 0}$ \\
\hline All Data & 594450 & 232315 & 108247 & 59638 & 19089 & 8320 \\
\hline $\mathbf{5}$ and Over & 30212 & 25496 & 19448 & 14660 & 7205 & 3832 \\
\hline $\mathbf{1 0}$ and Over & 8517 & 8196 & 7461 & 6427 & 3948 & 2501 \\
\hline $\mathbf{2 0}$ and Over & 2950 & 2853 & 2764 & 2651 & 2075 & 1594 \\
\hline $\mathbf{1 0 0}$ and Over & 794 & 794 & 794 & 792 & 693 & 560 \\
\hline
\end{tabular}

101 Figure 1 Variability in NCI60 GI50 data. A) Overview of the principle of the $\mathrm{NCI} 60$ screen. B)

102 Compound/ cell line combinations with two or more experiments in the NCl60 database. C) GI50 fold changes in dependence on the number of experiments per compound/ cell line combination.

104 Numerical data are presented in the adjacent table. D) Distribution of maximum GI50 fold changes

105 illustrated by density plots for experimental compound/cell line combination groups with an increasing

106 minimum number of experiments. E) Percentage of compound cell line combinations with maximum

107 fold changes above the indicated thresholds in dependence of the number of experiments. Numerical 108 data are presented in the adjacent table. F) Distribution of Gl50 fold changes in dependence of the 
109

110

111

112

113

114

115

116

117

118

119

120

121

122

123

124

125

126

127

128

129

130

131

132

133

concentration ranges in which compounds were tested. Numerical data are presented in the adjacent table.

\section{Variability increases with the concentration range covered}

The observed fold changes also reflected the tested concentration ranges per

compound/ cell line combination in addition to the number of experiments, i.e. the broader the range of concentrations that were tested, the larger was the maximum fold change (Figure 1D, Extended Data Table 8). A positive correlation was observed between concentration range and maximum fold change for all compound data (Spearman correlation coefficient $\left.=0.31, \mathrm{p}<2.2 \times 10^{-16}\right)($ Extended Data Figure $3 \mathrm{~B})$.

The mean and median GI50 fold changes for compound/ cell line combinations for which a maximum concentration range $<1.0 \times 10^{5}$ was covered were 146.8 and 1.5 , which increased to $68,121,059$ and 289,734 for those with a concentration range of $\geq 1.0 \times 10^{9}$ (Figure 1F, Extended Data Table 8).

\section{Variability in FDA Approved Drugs}

Since reliable clinical therapy outcomes depend on reproducible drug effects,

it may be speculated that FDA-approved drugs are more robust in their drug response data than experimental agents. However, the drug response data observed for FDA-approved drugs displayed a similar variability like that observed across all tested compounds.

The NCI60 database contained data on 181 FDA-approved drugs, which had been tested at least twice, resulting in 399,686 experiments investigating 9,970 individual drug/cell line combinations (Extended Data Table 1). The number of experiments for drug/cell line combinations ranged from 2 to 2,286. 
134 The maximum GI50 fold change was $1.25 \times 10^{10}$ observed for mithramycin in

135 four cell lines, the colorectal cancer cell line COLO-205 (26 experiments) (Extended

136 Data Figure 1B), the CNS cell lines SF-295 (24 experiments) and U251 (27

137 experiments), and the ovarian cancer cell line IGROV1 (26 experiments).

138 Mithramycin, a member of the aureolic acid family was approved in 1970 but only

139 temporarily used for testicular carcinoma and other types of cancer due to serious

140 side effects [52]. The second highest GI50 fold change $\left(7.28 \times 10^{7}\right)$ was detected for

141 paclitaxel, a stabilising tubulin-binding agent and one of the most commonly used

142 anti-cancer drugs [53], in MDA-MB-435 (Extended Data Figure 1C), which had

143 originally been assumed to be a breast cancer cell line, but was later found to be

144 derived from the melanoma cell line M14 [54].

145 The maximum GI50 fold changes were higher among the FDA approved

146 drugs than for the non-FDA approved compounds (Figure 2A, Extended Data Table

147 9), probably because they were tested in more experiments and at bigger

148 concentration ranges (Figure 2A).

149 When we considered the percentage of FDA-approved drug/ cell line

150 combinations with maximum GI50 fold changes $>2,>5,>10,>100$, and $>1000$ for

151 combinations with $>5,>10,>20$, and $>100$ experiments (Figure 2B, Figure 2C,

152 Extended Data Table 7, Extended Data Table 10), we obtained similar results to

153 those across all compounds (Figure 1E).

154 In agreement with the findings across all compound/ cell line combinations,

155 the maximum Gl50 fold changes also increased with experiment number when the

156 FDA approved drug/ cell line combinations were grouped into combinations with two

157 experiments, 3 to 5 experiments, 6 to 20 experiments, and >20 experiments (Figure

158 2D, Suppl. Table 11), and the maximum Gl50 fold change was also correlated with 
159 the number of experiments performed (Spearman's correlation coefficient $=0.72, p<$

$\left.1602.2 \times 10^{-16}\right)($ Extended Data Figure 3C).

161 Moreover, the maximum GI50 fold change increased with the concentration

162 range covered (Figure 2E, Extended Data Table 12), and there was a significant

163 correlation between the concentration range and the maximum GI50 fold change

164 (Spearman's correlation coefficient $\left.=0.62, p<2.2 \times 10^{-16}\right)($ Extended Data Figure

165 3D).

166 Taken together, there is no indication that FDA-approved drugs would display

167 less variability than experimental compounds.

168 

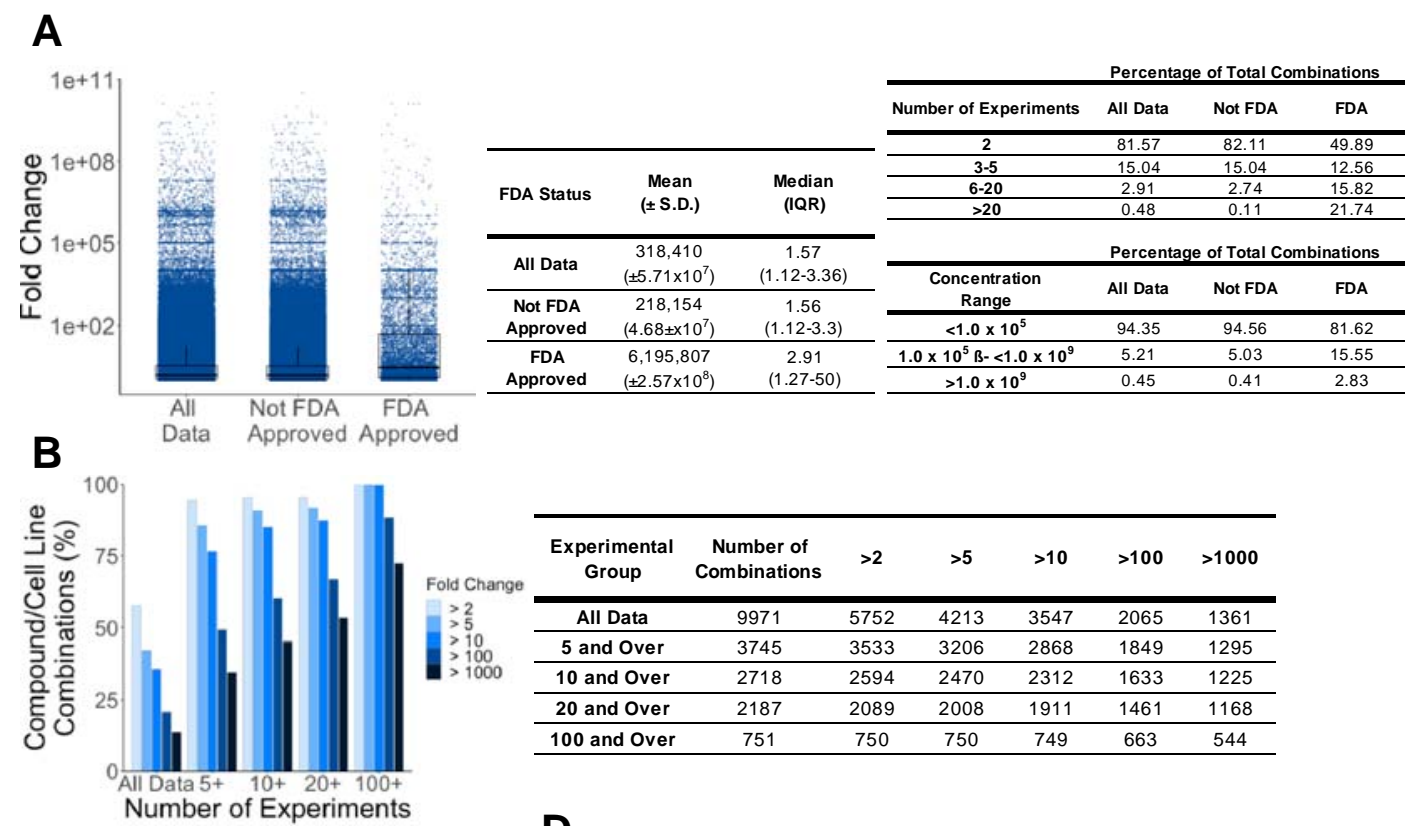

\begin{tabular}{ccccccc}
\hline $\begin{array}{c}\text { Experimental } \\
\text { Group }\end{array}$ & $\begin{array}{c}\text { Number of } \\
\text { Combinations }\end{array}$ & $\mathbf{> 2}$ & $\mathbf{> 5}$ & $\mathbf{> 1 0}$ & $\mathbf{> 1 0 0}$ & $>\mathbf{1 0 0 0}$ \\
\hline All Data & 9971 & 5752 & 4213 & 3547 & 2065 & 1361 \\
\hline $\mathbf{5}$ and Over & 3745 & 3533 & 3206 & 2868 & 1849 & 1295 \\
\hline $\mathbf{1 0}$ and Over & 2718 & 2594 & 2470 & 2312 & 1633 & 1225 \\
\hline $\mathbf{2 0}$ and Over & 2187 & 2089 & 2008 & 1911 & 1461 & 1168 \\
\hline $\mathbf{1 0 0}$ and Over & 751 & 750 & 750 & 749 & 663 & 544 \\
\hline
\end{tabular}

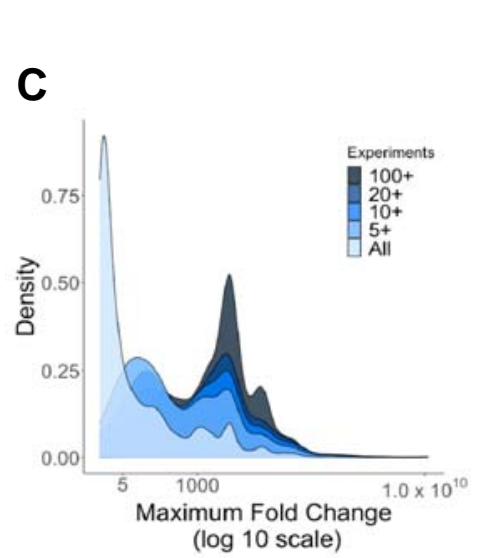

169

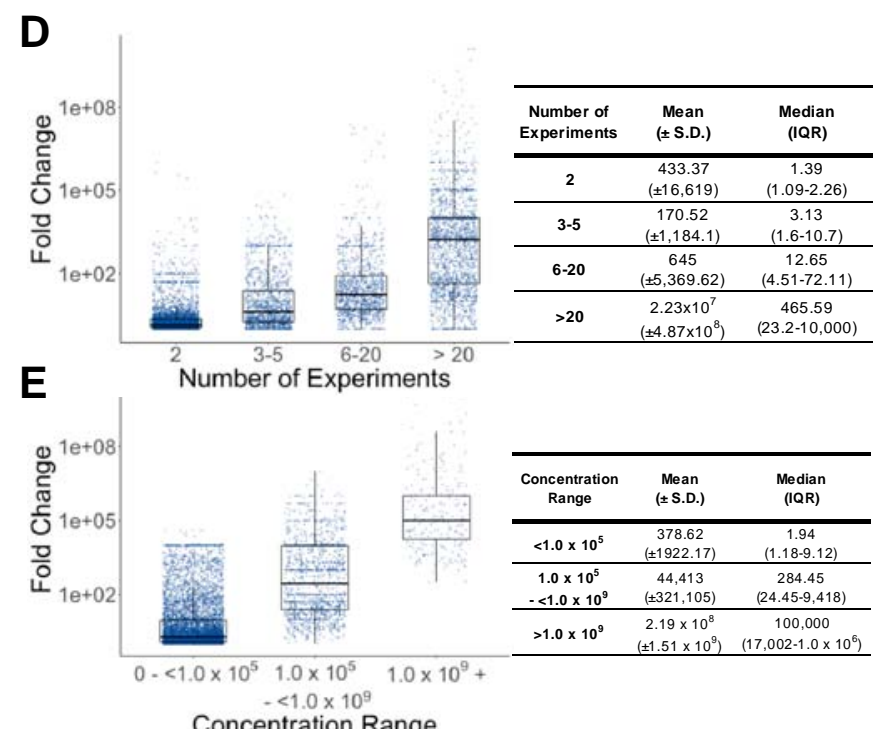

170 Figure 2. GI50 variation for FDA-approved drugs. A) Compound/ cell line combinations with 2 or

171 more experiments in the $\mathrm{NCl} 60$ database. Numerical data are presented in the adjacent tables. B)

172 Percentage of FDA-approved drug/ cell line combinations with maximum fold changes above the

173 indicated thresholds in dependence of the number of experiments. Numerical data are presented in

174 the adjacent table. C) Distribution of maximum GI50 fold changes illustrated by density plots for

175 experimental compound/cell line combination groups with increasing minimum numbers of

176 experiments. D) GI50 fold changes in dependence on the number of experiments per compound/ cell

177 line combination. Numerical data are presented in the adjacent table. (E) Distribution of GI50 fold 
178 changes in dependence of the concentration ranges in which compounds were tested. Numerical data

179 are presented in the adjacent table.

180

181

\section{GI50 variability in experiments performed by month}

The reproducibility of results may be affected by parameters such as changes

in the reagents, e.g. use of different lots or batches, different experimenters, and

using cell lines at different passages [2,55-57]. Hence, experiments performed

closely together may be expected to display greater similarity than experiments

187 performed at more distant points in time during the decades of anti-cancer

compound testing by the $\mathrm{NCl} 60$.

To investigate the effects of the time of testing on data variability, we

compared experiments performed in the same month to control samples of the same

191 size that were randomly selected across the whole testing period. For this analysis,

192 we used the 18 FDA-approved drugs that were tested at least 100 times in at least

193 one cell line over periods of 95 to 275 months (Figure 3A, Extended Data Table 13),

194 resulting in $51,872 \mathrm{drug} / \mathrm{cell}$ line combinations and in total 321,709 experiments

195 (Figure 3B, Suppl. Table 14).

196 For every set of experiments performed on the same date, we generated

1971,000 random control samples of the same size and compared the value distribution.

198 The variability of G150 fold changes for same date experiments was indeed lower

199 than for random control samples, but remained very high reaching up to $1.74 \times 10^{8}$

200 (Figure 3C, Extended Data Table 15). Moreover, for $45 \%$ of the same date drug/ cell

201 line combinations the GI50 fold change was higher than the mean fold change of the

202 corresponding 1,000 random samples (Figure 3D, Extended Data Table 16). 
203 When we looked at the data per cell line, the same date Gl50 fold changes

204 were higher than the mean random sample fold changes for the majority of drugs in

205 ten cell lines, higher for half of the drugs in three cell lines, and lower for the majority

206 drugs in the remaining 47 cell lines (Figure 3E, Extended Data Table 17). When we

207 looked at the individual drugs, six displayed a majority of drug/cell line combinations

208 with higher mean same date GI50 fold changes higher than in the random samples

209 and twelve drugs displayed lower ones (Figure 3F, Extended Data Table 18).

210 Taken together, experiments performed in close timely proximity display lower

211 variability than experiments performed over a longer time period, but the same date

212 variability remains very high. 
A

D
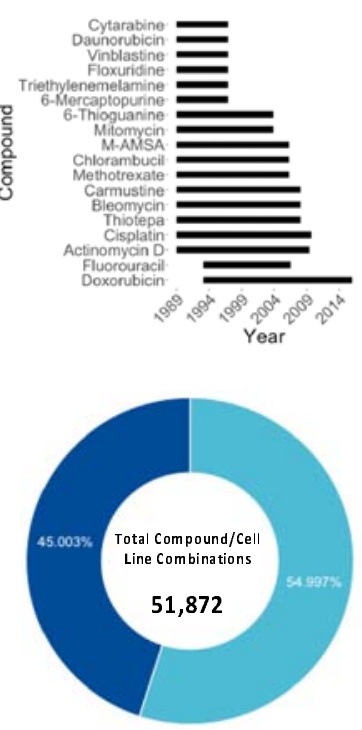

Same date GI50 fold change higher Same date GI50 fold change lower

G

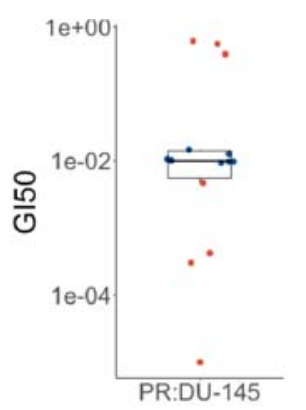

H

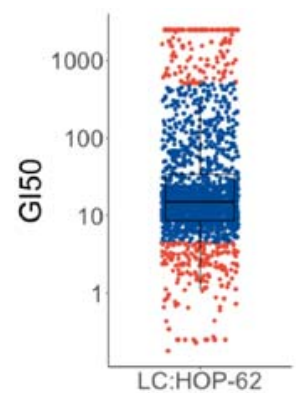

B

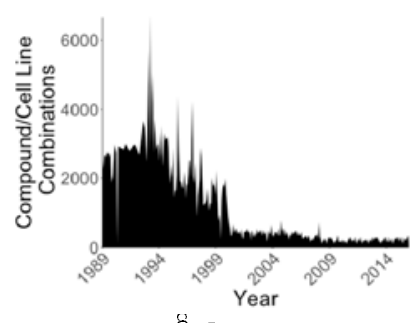

E
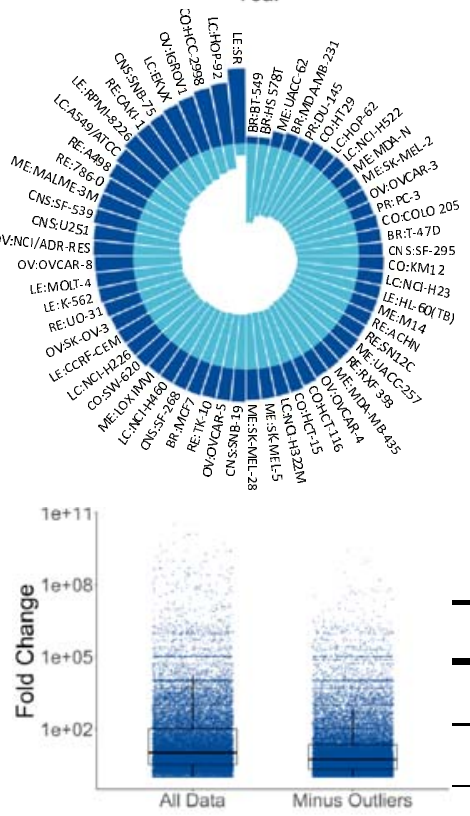

$\mathbf{F}$
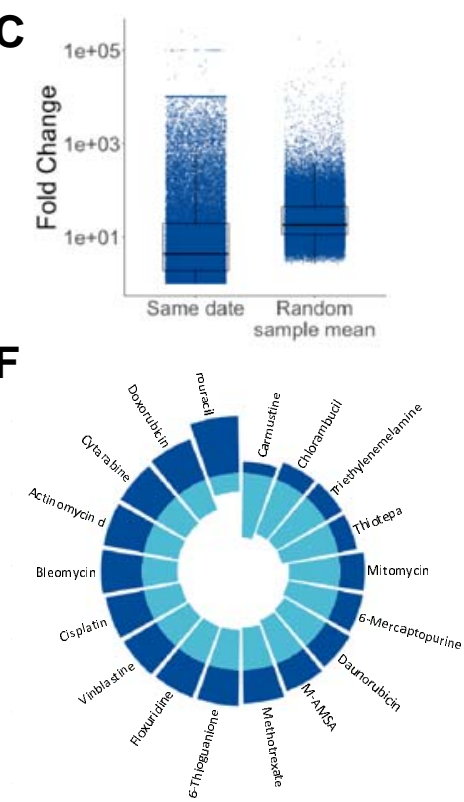

\begin{tabular}{ccc} 
Data & $\begin{array}{c}\text { Mean } \\
( \pm \text { S.D. })\end{array}$ & $\begin{array}{c}\text { Median } \\
(\text { IQR })\end{array}$ \\
\hline All & $\begin{array}{c}318,410 \\
\left( \pm 5.71 \times 10^{7}\right)\end{array}$ & $\begin{array}{c}1.57 \\
(1.12-3.36)\end{array}$ \\
\hline Minus & 195,907 & 5.21 \\
Outliers & $\left( \pm 1.63 \times 10^{7}\right)$ & $(2.1-21.9)$ \\
\hline
\end{tabular}

\section{$\mathbf{J}$}

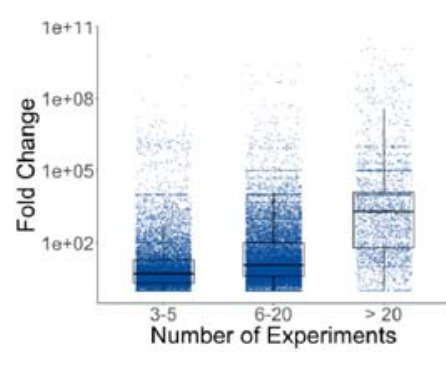

K

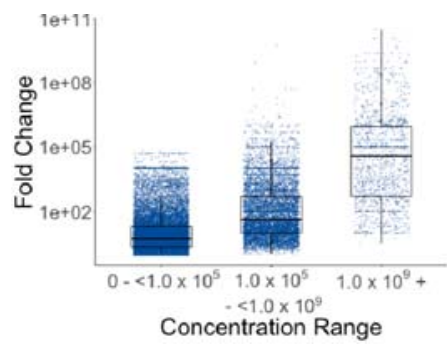

\begin{tabular}{ccc}
\hline $\begin{array}{c}\text { Number of } \\
\text { Experiments }\end{array}$ & $\begin{array}{c}\text { Mean } \\
( \pm \text { S.D.) }\end{array}$ & $\begin{array}{c}\text { Median } \\
(\text { IQR })\end{array}$ \\
\hline $3-5$ & $\begin{array}{c}15,601 \\
\left( \pm 5.35 \times 10^{5}\right)\end{array}$ & $\begin{array}{c}2.76 \\
(1.42-7.48)\end{array}$ \\
\hline $6-20$ & $\begin{array}{c}80,079 \\
\left( \pm 8.01 \times 10^{6}\right)\end{array}$ & $\begin{array}{c}6.98 \\
(2.82-27.23)\end{array}$ \\
\hline$>20$ & $\begin{array}{c}1.66 \times 10^{6} \\
\left( \pm 5.08 \times 10^{7}\right)\end{array}$ & $\begin{array}{c}69.34 \\
(10-2,231)\end{array}$ \\
\hline \multicolumn{3}{c}{} \\
\end{tabular}

\begin{tabular}{ccc}
\hline $\begin{array}{c}\text { Concentration } \\
\text { Range }\end{array}$ & $\begin{array}{c}\text { Mean } \\
( \pm \text { S.D. })\end{array}$ & $\begin{array}{c}\text { Median } \\
(\mathbf{I Q R})\end{array}$ \\
\hline$<1.0 \times 10^{\mathbf{5}}$ & $\begin{array}{c}281.03 \\
( \pm 2477.7)\end{array}$ & $\begin{array}{c}3.42 \\
(1.61-9.35)\end{array}$ \\
\hline $\mathbf{1 . 0 \times 1 0 ^ { 5 }}$ & 22,254 & 12.13 \\
$-<1.0 \times 10^{9}$ & $\left( \pm 9.39 \times 10^{5}\right)$ & $(4.45-91)$ \\
\hline$>\mathbf{1 . 0 \times 1 0 ^ { 9 }}$ & $3.93 \times 10^{6}$ & 1803 \\
& $\left( \pm 7.4 \times 10^{7}\right)$ & $(81.66-100,000)$ \\
\hline & &
\end{tabular}

215 Figure 3 GI50 variability is high between compound/cell line combination experiments on the

216 same date and is not caused by outliers. A) Time periods of drug testing for individual drugs. B)

217 Testing of individual compound/cell line combinations by date. C) Maximum Gl50 fold changes in

218 experiments testing compound/ cell line combinations on the same date compared to maximum GI50 
219 fold changes in 1000 random controls of the same sample size. D) Percentage of cases in which

220 same date experiments had a higher fold change than control samples randomly picked across the

221 timeline. E) Proportion of same date GI50 fold changes in compound/ cell line combinations that are

222 higher or lower than random control samples per cell line. F) Proportion of same date GI50 fold

223 changes in compound/ cell line combinations that are higher or lower than random control samples

224 per drug. G) GI50 value distribution for maytansine in the prostate cancer cell line DU-145 (outliers

225 indicated in red). H) GI50 value distribution for for 5-fluorouracil in the lung cancer cell line HOP-62

226 (outliers indicated in red). I) Comparison of maximum GI50 fold changes before and after removal of

227 outliers. Numerical values are presented in the adjacent table. J) Maximum GI50 fold changes

228 increase with experiment number after removal of outliers. Numerical values are presented in the

229 adjacent table. K) Maximum GI50 fold changes increase with the concentration range covered after

230 removal of outliers. Numerical values are presented in the adjacent table.

232 High GI50 variability is not caused by outliers

233 Finally, we determined GI50 outliers for compound/cell line combinations with

2345 or more experiments (738 compounds, 30,212 compound/cell line combinations,

235598,243 GI50 values) using the adjusted boxplot method [58]. 5.7\% (34,216) of GI50

236 values were outliers and $43.7 \%(13,208 / 30,212)$ of compound/cell line combinations

237 had at least one GI50 outlier (Extended Data Table 19). This indicates that outliers

238 are not responsible for the observed variability of GI50 in the majority (56.3\%) of

239 experiments.

240 The highest percentage of outliers was 50\% (7/14 experiments for maytansine

241 in DU-145 prostate cancer cells) (Figure 3G, Extended Data Table 19). The greatest

242 number of outliers was 291 (16.8\%) out of 1731 experiments for 5-fluorouracil in

243 HOP-62 lung cancer cells (Figure 3H, Extended Data Table 19). Outlier number

244 increased with the number of experiments for a compound/cell line combination with

245 a Spearman correlation coefficient of $0.25\left(p<2.2 \times 10^{-16}\right)$ (Extended Data Figure 4). 
246 The removal of outliers reduced data variability, but the overall variability remained

247 very high with a maximum GI50 fold range of $2.5 \times 10^{9}$ detected for maytansine in

248 the ovarian cancer cell line OVCAR-5 over 35 experiments (Figure 3I, Extended

249 Data Table 19).

250 As detected in the analysis across all experiments, maximum GI50 fold

251 changes increased with the number of experiments and the concentration ranges

252 covered also after the removal of outliers (Figure 3J, Figure 3K, Extended Data

253 Table 19, Extended Data Table 20). A significant correlation was observed between

254 experiment number and maximum GI50 fold change with a Spearman correlation of

$2550.39\left(p<2.2 \times 10^{-16}\right)$ (Extended Data Figure 5A) and between concentration range

256 and maximum GI50 fold change with a Spearman correlation of $0.47\left(\mathrm{p}<2.2 \times 10^{-16}\right)$

257 (Extended Data Figure 5B).

258

259 No drift in drug sensitivity over time

260 Cancer cell lines may display substantial changes in genotype and phenotype

261 over time [55,59]. Hence, part of the variability observed in drug sensitivity may be

262 the consequence of a shift in drug response over time. To investigate this, we

263 established timelines of the GI50 values for the 18 compounds, which had been

264 tested at least 100 times in one or more cell lines. This resulted in time lines for 1080

265 compound/cell line combinations with time frames ranging from 95 months

266 (vinblastine, floxuridine, cytarabine, daunorubicin, 6-mercaptopurine) to 275 months

267 (Doxorubicin) (Figure 3A, Extended Data Table 13).

268 Drug/ cell line combinations, in which the fold change between the mean GI50

269 on the first experimental date and the mean GI50 on the last experimental date was

$27050 \%$ or greater than the maximum Gl50 fold change for the data points in between 
271 were considered as candidates for a drift in drug sensitivity. Only six $(0.56 \%)$ out of

2721080 drug/cell line combinations fulfilled these criteria (Figure 4, Extended Data

273 Table 21).

274 The distribution of the individual GI50 values for three of the drug/ cell line

275 combinations (floxuridine/ SK-OV-3, methotrexate/ BT-549, 6-mercaptopurine/ BT-

276 549) did not indicate a GI50 shift over time (Figure 4A-C, Extended Data Table 21,

277 Extended Data Table 22). For the other three drug/ cell line combinations

278 (vinblastine/ T-47D, bleomycin/ K-562, M-AMSA/ MDA-MB-435) a drift in sensitivity

279 appears unlikely but cannot be excluded based on the data (Figure 4D-E, Extended

280 Data Table 21, Extended Data Table 22). However, such observations are very rare.

281 Moreover, a phenotypic drift in a cell line would be expected to result in changes in

282 sensitivity to more than one drug over time. Hence, the data provide no evidence

283 suggesting that the drug sensitivity of individual cell lines may have changed over

284 time. These findings may also reflect that the $\mathrm{NCl} 60$ uses cell lines within a window

285 of 30 passages [60].

A

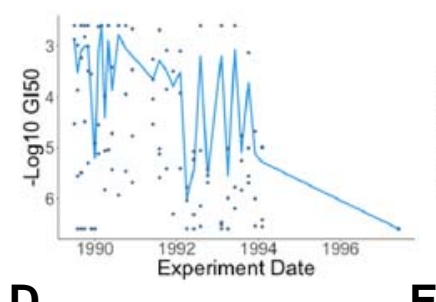

D

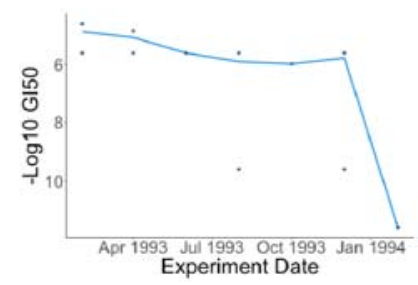

B
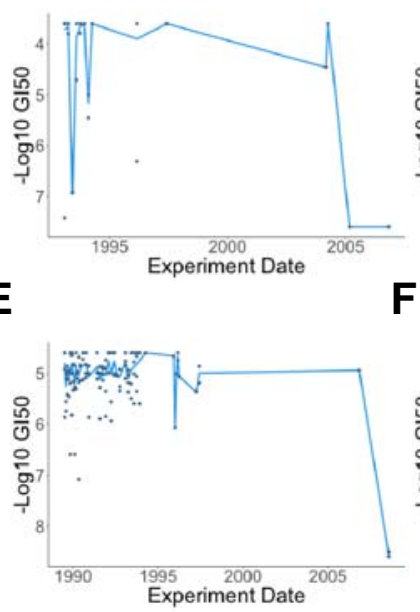

C

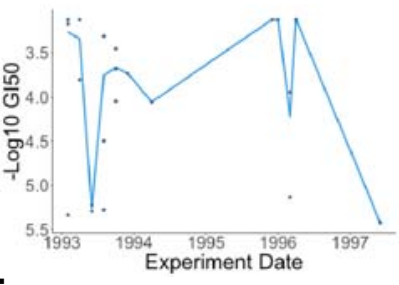

$\mathbf{F}$

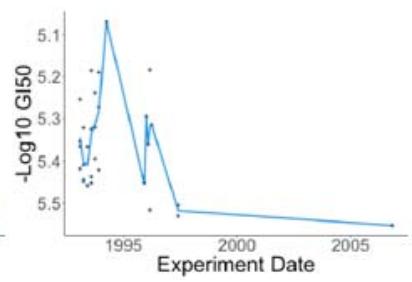


288 Figure 4 Experimental time lines for individual compound/cell line combinations. The six

289 experimental timelines for compound/cell line combinations (with more than 100 experiments

290 performed in at least one cell line) with a fold change between the first and last mean GI50 that is

$29150 \%$ greater than the maximum GI50 for the remaining experiments. A) floxuridine in the ovarian

292 cancer cell line SK-OV-3, B) methotrexate in the breast cancer cell line BT-549, C) 6-mercaptopurine

293 in the breast cancer cell line BT-549, D) bleomycin in the leukaemia cell line K-562, E) vinblastine in

294 the breast cancer cell line T-47D, F) M-AMSA in the melanoma cell line MDA-MB-435. Plot lines

295 represent mean GI50s while data points represent individual experiments at an experimental date. 


\section{Discussion}

298 To gain real-life insights into the extent of data variability in a standardised

299 research environment, we here investigated the variation of GI50 values indicating

300 drug sensitivity for compounds that had been tested multiple times in the $\mathrm{NCI} 60$

301 panel. The variation was large with the highest fold change between the lowest and

302 highest GI50 in a given compound/cell line combination being $3.16 \times 10^{10}$. As might

303 have been expected, the fold change between the lowest and the highest GI50 in a

304 specific compound cell line combination increased with the number of experiments

305 and the concentration range tested.

306 CellMiner contains data on experimental compounds as well as on FDA-

307 approved drugs that are in clinical use [4,46-51]. Although FDA-approved drugs

308 might have been expected to result in more robust data, this was not the case and

309 they displayed a similar data variability as that determined across all compounds.

310 The variability also remained very high when we only considered experiments that

311 were performed in the same months or removed outliers.

312 Given that the $\mathrm{NCl} 60$ uses highly standardised methods, a high variability of

313 assay results appears to be an intrinsic feature of lab experiments. The large range

314 of GI50 values observed for anti-cancer drugs is of potential relevance, given that

315 cytotoxic anti-cancer drugs are typically used at maximum tolerated doses that

316 cannot be further increased without unacceptable toxicity [61-63]. Moreover, the

317 maximum effects of targeted drugs, e.g. antibodies or kinase inhibitors that interfere

318 with cancer-specific structures or entities, do not further increase beyond the 'optimal

319 biological dose', i.e. the dose at which the biological target is completely inhibited

320 [61-64]. Hence, even a two-fold difference in the GI50, which occurred in 25,496

$321(84.4 \%)$ of 30,212 compound/cell line combinations with at least five experiments, is 
322 of potential relevance, as a two-fold increase of the clinical dose of an anti-cancer

323 drug is rarely feasible.

324 Notably, there is awareness of this variability within the NCI60 project as

325 indicated by strict quality control procedures in the presentation of $\mathrm{NCI} 60 \mathrm{GI} 50$

326 values in CellMiner, which result in the exclusion of up to $96 \%$ of experiments (48 out

327 of 50) for a given compound/ cell line combination (Extended Data Table 23) [4].

328 However, such knowledge has not penetrated into scientific discourse. Many

329 authors promote strict standardisation of experimental procedures as a strategy to 330 improve data quality and reliability $[2,5,15,45,65-71]$.

331 Our analysis of NCl60 data, which is of unprecedented depth and provided by 332 a world-leading institution with unprecedented transparency, indicates that data 333 variation remains very high even under ideal conditions that the vast majority of 334 research groups will not be able to afford. Hence, our data suggest that experiment 335 heterogenization, the testing of a hypothesis in many different (experimental) 336 systems and datasets and different laboratories [72-79], is a much better strategy to 337 generate robust and meaningful data.

338 In conclusion, our analysis demonstrates that the variation of experimental 339 data is extremely high even under optimal conditions in a world-leading environment 340 applying the highest standards. This shows that increased standardisation is not a 341 straightforward way to resolve issues associated with limited replicability. Hence, 342 increased data robustness will have to include additional strategies such as 343 independent replication and experiment heterogenization, i.e. multiple testing of the 344 same hypothesis using different approaches and models. Awareness of the inherent 345 variability of experimental results, will help researchers to develop a realistic 
bioRxiv preprint doi: https://doi.org/10.1101/2021.02.27.433153; this version posted February 28, 2021. The copyright holder for this preprint

(which was not certified by peer review) is the author/funder, who has granted bioRxiv a license to display the preprint in perpetuity. It is made available under aCC-BY-NC-ND 4.0 International license.

346 understanding of the meaning of their data and to design more diverse research

347 strategies that will result in higher data robustness and reliability.

348

349 


\section{Methods}

351

\section{Data Availability}

353 All data were obtained from CellMiner [80] Version 2.2. Dose concentration

354 range data (June 2018 release) were obtained from the National Cancer Institute 355 DTP $\mathrm{NCl}$ bulk data for download pages

356 (https://wiki.nci.nih.gov/display/NCIDTPdata/NCI-60+Growth+Inhibition+Data). Of the

$35752,585 \mathrm{NCl}$ codes given to compounds tested on the $\mathrm{NCl}-60$ cell line panel, 42,794

358 were given to unnamed compounds and 9,791 were given to 9,027 named

359 compounds. 262 named compounds received two or more individual codes. Some

360 GI50 values represent minimum or maximum drug concentrations where the actual

361 GI50 was not reached [4]. Since such values understate the actual data variation, we

362 did not remove these data. All data generated during this study are included in this

363 published article and its supplementary information files.

364

365 Maximum GI50 fold change calculation

366 The drug sensitivity data was converted from - $\log 10 \mathrm{GI} 50$, to the $\mathrm{GI} 50(\mu \mathrm{M})$

367 for all compound, all cell lines and all experiments. Maximum fold changes were

368 calculated for each compound/cell line combination with more than one experiment

$369(594,450)$ by dividing the maximum GI50 for a cell line by the minimum GI50.

\section{Number of experiments and experimental groups}

372 The number of experiments for each individual compound/cell line

373 combination was calculated by counting all experiments performed on the same 374 experimental date as well as experiments on different dates. The relationship 
375 between number of experiments and maximum fold change was investigated by

376 using Spearman's correlation coefficient as the distribution of maximum GI50 fold

377 change was not normal.

378 The compound/cell line combinations were then assigned experimental

379 groupings base on the number of experiments performed: all data, 5 or more

380 experiments, 10 or more experiments, 20 or more experiments, and 100 or more

381 experiments. This allowed comparison of "high" maximum fold changes $(>2,>5,>10$,

$382>100$, and $>1000$ ) for combinations with varied number of experiments. Additionally,

383 compound/cell line combinations were assigned to experimental groups: 2

384 experiments, 3 to 5 experiments, 6 to 20 experiments and over 20 experiments.

385 These experimental groupings enabled comparison of GI50 fold change statistics

386 (mean, median, minimum, maximum, variance) for compound/cell line combinations

387 with number of experiments ranging from lower to higher.

388

389 Concentration range and experimental groups

Maximum dose concentration range for a compound/cell line combination was

391 determined by using the minimum and maximum dose concentration used in an

392 experiment for an individual compound on an individual cell line. The minimum

393 concentration range was $1.0 \times 10^{1.2}$ and the maximum concentration was $1.0 \times$

$39410^{12.1}$. The relationship between dose concentration range and maximum fold

395 change was investigated by using Spearman's correlation coefficient as the

396 distribution of maximum GI50 fold change was not normal.

397 Compound/cell line combinations were assigned to groups based on the dose

398 concentration range for that combinations: maximum concentration range less than

$3991.0 \times 10^{5}$, maximum concentration range $1.0 \times 10^{5}$ to $1.0 \times 10^{9}$ exclusive and 
400 maximum concentration range $1.0 \times 10^{9}$ and above. These experimental groupings

401 enabled comparison of GI50 fold change statistics (mean, median, minimum,

402 maximum, variance) for compound/cell line combinations between lower and higher

403 concentration ranges.

404

\section{FDA-approved compound analysis}

406 All compounds that were classed as FDA-approved drugs by the $\mathrm{NCl}-60$ in 407 CellMiner Database Version 2.2 and where two or more experiments had been 408 performed were extracted from the complete dataset. This created an FDA-approved 409 dataset of 181 drugs for which 399,686 experiments for 9,970 individual drug/cell line 410 combinations were performed. Analysis of relationship between the number of 411 experiments/concentration ranges and maximum GI50 fold change for drug/cell line 412 combinations was performed as for the complete dataset, described above.

\section{Experiments on the same date}

415 Month and year of each experiment was available so experimental timelines

416 were established for compounds by calculating the time between the first and last 417 experiment date. Multiple experiments were carried out on the same date for many 418 of the compound/cell line combinations, particularly the 18 compounds with at least 419 one cell line with 100 total experiments. The data for these 18 compounds, 17 of 420 which were FDA-approved, was extracted from the complete dataset to create a 421 subset of data deemed suitable to compare GI50 variability on the same date with 422 GI50 variability over an experimental timeline.

423 The maximum Gl50 fold change on each date where there were multiple 424 experiments for a compound/cell line combination were calculated by dividing 
425 maximum GI50 by minimum GI50 value. The number of experiments on a specific

426 date for a compound/cell line combination was used to determine the maximum GI50

427 fold change over the same number of experiments picked randomly from that

428 combination's experimental timeline. This was performed 1000 times so that for

429 every compound/cell line combination and experimental date with a maximum GI50

430 fold change over multiple experiments there were 1000 corresponding maximum

431 Gl50 fold changes calculated from random samples of the same number of

432 experiments on that compound/cell line combination's timeline. The mean maximum

433 GI50 fold change was calculated for the 1000 random samples for each

434 compound/cell line combination and the number of maximum GI50 fold changes for

435 experiments on the same date higher and lower than the random sample mean were

436 counted. For each compound, significance of the difference between same date

437 maximum GI50 fold change and sample mean GI50 fold change was calculated

438 using Wilcoxon Rank Sum Test. This was performed using all cell line data

439 combined for each compound and for each cell line individually for each compound.

440 Where a significant difference between same date and random sample mean

441 maximum GI50 fold changes were observed, the number of times the same date

442 GI50 fold change was higher or lower than the random sample mean maximum GI50

443 fold change was counted.

\section{Drift in drug sensitivity}

446 The mean Gl50 fold change was calculated for each experimental date 447 (month) for the 18 compounds with 100 or more experiments for at least one cell 448 line. The G150 fold change between the first experimental date and the last 449 experimental date was calculated using the mean GI50 on those dates. The first/last 
450 GI50 fold change was then compared to the maximum GI50 fold change for each

451 compound/cell line combination and considered a candidate for a drift in sensitivity if

452 it was $50 \%$ or more of the maximum fold change.

453

454 Removal of outliers

455 The adjusted boxplot method was used to identify outlier thresholds. This 456 method was chosen as the data set was highly skewed. To use this method the 457 medcouple $(M C)$, a robust measure of skewness, had to be calculated (where $458 X_{n}=\left\{x_{1}, x_{2}, \ldots, x_{n}\right\}$ represents data for every compound/cell line combination):

459

$$
M C\left(x_{1}, \ldots, x_{n}\right)=\operatorname{med} \frac{\left(x_{j}-\operatorname{med}_{k}\right)-\left(\operatorname{med}_{k}-x_{i}\right)}{x_{j}-x_{i}}
$$

460

461 Where $\operatorname{med}_{k}$ is the median of $X_{n}$, and $i$ and $j$ have to satisfy $x_{i} \leq \operatorname{med}_{k} \leq x_{j}$, and $462 x_{i} \neq x_{j}$.

$463 \quad$ Using the $M C$ the upper $(U)$ and lower $(L)$ thresholds could be determined. If

$464 M C \geq 0$ :

$$
\begin{gathered}
L=Q_{1}-1.5 \times \exp (-3.5 M C) \times I Q R \\
U=Q_{3}+1.5 \times \exp (4 M C) \times I Q R
\end{gathered}
$$

465

466 If $M C \leq 0$ :

$$
\begin{gathered}
L=Q_{1}-1.5 \times \exp (-4 M C) I Q R \\
U=Q_{3}+1.5 \times \exp (3.5 M C) \times I Q R
\end{gathered}
$$


468 If $M C=0$ the adjusted boxplot method was not used but instead the Tukey method

469 was used:

$$
\begin{aligned}
& L=Q_{1}-1.5 I Q R \\
& U=Q_{3}+1.5 I Q R
\end{aligned}
$$

470 Where $Q_{1}$ is the lower quartile, $Q_{3}$ is the upper quartile and $I Q R$ is the interquartile 471 range.

473 above $U$ were removed from the dataset. Analyses were performed on this dataset 474 as previously described for the complete dataset.

\section{Data processing}

479 Statistics::R were used. Packages used in $R$ were robustbase, dplyr, webr, 480 moonBook, tidyverse, reshape2, scales, gplots, ggpubr, ggExtra, RColorBrewer, 481 corrplot, ggplot2, and tidyr. 


\section{Author contributions}

488 Data acquisition and analysis (I.R.), data interpretation (all authors), study

489 conception (M.N.W., M.M.), study design (I.R., M.N.W., M.M.), manuscript drafting

490 (I.R., M.M.), manuscript revision (all authors).

491 All authors have approved the submitted version and agreed both to be 492 personally accountable for their own contributions and to ensure that questions 493 related to the accuracy or integrity of any part of the work, even ones in which they 494 were not personally involved, are appropriately investigated, resolved, and the 495 resolution documented in the literature.

496

497 Conflicts of interest

498 The authors declare no competing interests.

499

500 Data availability

501 All raw data are available from CellMiner [80] Version 2.2. All other data are 502 provided in the manuscript and its supplements.

503 


\section{References}

505 1. França TF, Monserrat JM. Reproducibility crisis in science or unrealistic 506 expectations? EMBO Rep. 2018 Jun;19(6). pii: e46008.

507 2. Wass MN, Ray L, Michaelis M. Understanding of researcher behavior is required 508 to improve data reliability. Gigascience. 2019 May 1;8(5). pii: giz017.

509 3. Shoemaker $\mathrm{RH}$. The NCl60 human tumour cell line anticancer drug screen. Nat 510 Rev Cancer. 2006 Oct;6(10):813-23.

511 4. Reinhold WC, Sunshine M, Liu H, Varma S, Kohn K, Morris J, Doroshow J and

512 Pommier Y. CellMiner: a web-based suite of genomic and pharmacologic tools to

513 explore transcript and drug patterns in the NCl-60 cell line set. Cancer Res. 2012 Jul 514 15; 72(14): 3499-3511.

515 5. Begley CG, loannidis JP. Reproducibility in science: improving the standard for 516 basic and preclinical research. Circ Res. 2015 Jan 2;116(1):116-26.

517 6. Frye SV, Arkin MR, Arrowsmith CH, Conn PJ, Glicksman MA, Hull-Ryde EA, 518 Slusher BS. Tackling reproducibility in academic preclinical drug discovery. Nat Rev 519 Drug Discov. 2015 Nov;14(11):733-4.

520 7. Drucker DJ. Never Waste a Good Crisis: Confronting Reproducibility in 521 Translational Research. Cell Metab. 2016 Sep 13;24(3):348-360.

522 8. Fanelli D. Opinion: Is science really facing a reproducibility crisis, and do we need 523 it to? Proc Natl Acad Sci U S A. 2018 Mar 13;115(11):2628-2631.

524 9. Samsa G, Samsa L. A Guide to Reproducibility in Preclinical Research. Acad 525 Med. 2019 Jan;94(1):47-52.

526 10. Munafò MR, Chambers CD, Collins AM, Fortunato L, Macleod MR. Research 527 Culture and Reproducibility. Trends Cogn Sci. 2020 Feb;24(2):91-93. 
528 11. Mobley A, Linder SK, Braeuer R, Ellis LM, Zwelling L. A survey on data

529 reproducibility in cancer research provides insights into our limited ability to translate

530 findings from the laboratory to the clinic. PLoS One 2013;8(5):e63221.

531 12. Baker M. 1,500 scientists lift the lid on reproducibility. Nature 2016;533:452-4.

532 13. Nature Editorial. Checklists work to improve science. Nature 2018;556:273-4.

533 14. Prinz F, Schlange T, Asadullah K. Believe it or not: how much can we rely on

534 published data on potential drug targets? Nat Rev Drug Discov. 2011;10:712.

535 15. Begley CG, Ellis LM. Drug development: Raise standards for preclinical cancer 536 research. Nature 2012;483:531-3.

537 16. Aird F, Kandela I, Mantis C; Reproducibility Project: Cancer Biology. Replication 538 Study: BET bromodomain inhibition as a therapeutic strategy to target c-Myc. Elife 539 2017;6. pii: e21253.

540 17. Kandela I, Aird F; Reproducibility Project: Cancer Biology. Replication Study:

541 Discovery and preclinical validation of drug indications using compendia of public 542 gene expression data. Elife 2017;6. pii: e17044.

543 18. Shan X, Fung JJ, Kosaka A, Danet-Desnoyers G; Reproducibility Project: Cancer

544 Biology. Replication Study: Inhibition of BET recruitment to chromatin as an effective

545 treatment for MLL-fusion leukaemia. Elife 2017;6. pii: e25306.

546 19. Showalter MR, Hatakeyama J, Cajka T, VanderVorst K, Carraway KL, Fiehn O;

547 Reproducibility Project: Cancer Biology. Replication Study: The common feature of

548 leukemia-associated IDH1 and IDH2 mutations is a neomorphic enzyme activity

549 converting alpha-ketoglutarate to 2-hydroxyglutarate. Elife 2017;6. pii: e26030.

550 20. Essex A, Pineda J, Acharya G, Xin H, Evans J; Reproducibility Project: Cancer

551 Biology, lorns E, Tsui R, Denis A, Perfito N, Errington TM, lorns E, Tsui R, Denis A, 552 Perfito N, Errington TM. Replication Study: Wnt activity defines colon cancer stem 
553 cells and is regulated by the microenvironment. Elife. 2019 Jun 19;8. pii: e45426.

554 doi: 10.7554/eLife.45426.

555 21. Horrigan SK; Reproducibility Project: Cancer Biology. Replication Study: The

556 CD47-signal regulatory protein alpha (SIRPa) interaction is a therapeutic target for

557 human solid tumors. Elife 2017;6. pii: e18173.

558 22. Horrigan SK, Courville P, Sampey D, Zhou F, Cai S; Reproducibility Project:

559 Cancer Biology. Replication Study: Melanoma genome sequencing reveals frequent

560 PREX2 mutations. Elife 2017;6. pii: e21634. doi: 10.7554/eLife.21634.

561 23. Lewis LM, Edwards MC, Meyers ZR, Talbot CC, Hao H, Blum D, Reproducibility

562 Project: Cancer Biology, lorns E, Tsui R, Denis A, Perfito N, Errington TM.

563 Replication Study: Transcriptional amplification in tumor cells with elevated c-Myc.

564 Elife 2018;7. pii: e30274.

565 24. Eaton K, Pirani A, Snitkin ES; Reproducibility Project: Cancer Biology, lorns E,

566 Tsui R, Denis A, Perfito N, Errington TM. Replication Study: Intestinal inflammation

567 targets cancer-inducing activity of the microbiota. Elife 2018;7. pii: e34364.

568 25. Kim J, Afshari A, Sengupta R, Sebastiano V, Gupta A, Kim YH; Reproducibility

569 Project: Cancer Biology, lorns E, Tsui R, Denis A, Perfito N, Errington TM.

570 Replication study: Melanoma exosomes educate bone marrow progenitor cells

571 toward a pro-metastatic phenotype through MET. Elife. 2018 Dec 11;7. pii: e39944.

572 26. Vanden Heuvel JP, Maddox E, Maalouf SW; Reproducibility Project: Cancer

573 Biology, lorns E, Tsui R, Denis A, Perfito N, Errington TM. Replication Study:

574 Systematic identification of genomic markers of drug sensitivity in cancer cells. Elife 575 2018;7. pii: e29747.

576 27. Sheen MR, Fields JL, Northan B, Lacoste J, Ang LH, Fiering S; Reproducibility

577 Project: Cancer Biology, lorns E, Tsui R, Denis A, Perfito N, Errington TM. 
578 Replication Study: Biomechanical remodeling of the microenvironment by stromal

579 caveolin-1 favors tumor invasion and metastasis. Elife. 2019 Dec 17;8. pii: e45120.

580 doi: 10.7554/eLife.45120.

581 28. Kerwin J, Khan I; Reproducibility Project: Cancer Biology, lorns E, Tsui R, Denis

582 A, Perfito N, Errington TM. Replication Study: A coding-independent function of gene

583 and pseudogene mRNAs regulates tumour biology. Elife. 2020 Apr 21;9:e51019.

584 29. Mantis C, Kandela I, Aird F; Reproducibility Project: Cancer Biology. Replication

585 Study: Coadministration of a tumor-penetrating peptide enhances the efficacy of 586 cancer drugs. Elife 2017;6. pii: e17584. doi: 10.7554/eLife.17584.

587 30. Repass J; Reproducibility Project: Cancer Biology, lorns E, Denis A, Williams 588 SR, Perfito N, Errington TM. Replication Study: Fusobacterium nucleatum infection is 589 prevalent in human colorectal carcinoma. Elife 2018;7. pii: e25801.

590 31. Yan X, Tang B, Chen B, Shan Y, Yang H; Reproducibility Project: Cancer 591 Biology, lorns E, Tsui R, Denis A, Perfito N, Errington TM. Replication Study: The 592 microRNA miR-34a inhibits prostate cancer stem cells and metastasis by directly 593 repressing CD44. Elife. 2019 Mar 12;8. pii: e43511.

594 32. Wang H, Radomska HS, Phelps MA; Reproducibility Project: Cancer Biology, 595 Iorns E, Tsui R, Denis A, Perfito N, Errington TM. Replication Study: Coding596 independent regulation of the tumor suppressor PTEN by competing endogenous 597 mRNAs. Elife. 2020 Oct 19;9:e56651.

598 33. Fanelli D, Costas R, loannidis JP. Meta-assessment of bias in science. Proc Natl 599 Acad Sci U S A. 2017;114:3714-9.

600 34. Barretina J, Caponigro G, Stransky N, Venkatesan K, Margolin AA, Kim S, 601 Wilson CJ, Lehár J, Kryukov GV, Sonkin D, Reddy A, Liu M, Murray L, Berger MF, 602 Monahan JE, Morais P, Meltzer J, Korejwa A, Jané-Valbuena J, Mapa FA, Thibault 
603 J, Bric-Furlong E, Raman P, Shipway A, Engels IH, Cheng J, Yu GK, Yu J, Aspesi P

604 Jr, de Silva M, Jagtap K, Jones MD, Wang L, Hatton C, Palescandolo E, Gupta S,

605 Mahan S, Sougnez C, Onofrio RC, Liefeld T, MacConaill L, Winckler W, Reich M, Li

606 N, Mesirov JP, Gabriel SB, Getz G, Ardlie K, Chan V, Myer VE, Weber BL, Porter J,

607 Warmuth M, Finan P, Harris JL, Meyerson M, Golub TR, Morrissey MP, Sellers WR,

608 Schlegel R, Garraway LA. The Cancer Cell Line Encyclopedia enables predictive

609 modelling of anticancer drug sensitivity. Nature. 2012 Mar 28;483(7391):603-7.

610 35. Garnett MJ, Edelman EJ, Heidorn SJ, Greenman CD, Dastur A, Lau KW,

611 Greninger P, Thompson IR, Luo X, Soares J, Liu Q, Iorio F, Surdez D, Chen L,

612 Milano RJ, Bignell GR, Tam AT, Davies H, Stevenson JA, Barthorpe S, Lutz SR,

613 Kogera F, Lawrence K, McLaren-Douglas A, Mitropoulos X, Mironenko T, Thi H,

614 Richardson L, Zhou W, Jewitt F, Zhang T, O'Brien P, Boisvert JL, Price S, Hur W,

615 Yang W, Deng X, Butler A, Choi HG, Chang JW, Baselga J, Stamenkovic I,

616 Engelman JA, Sharma SV, Delattre O, Saez-Rodriguez J, Gray NS, Settleman J,

617 Futreal PA, Haber DA, Stratton MR, Ramaswamy S, McDermott U, Benes CH.

618 Systematic identification of genomic markers of drug sensitivity in cancer cells.

619 Nature. 2012 Mar 28;483(7391):570-5.

620 36. Haibe-Kains B, El-Hachem N, Birkbak NJ, Jin AC, Beck AH, Aerts HJ,

621 Quackenbush J. Inconsistency in large pharmacogenomic studies. Nature. 2013 Dec

$622 \quad 19 ; 504(7480): 389-93$.

623 37. Cancer Cell Line Encyclopedia Consortium; Genomics of Drug Sensitivity in

624 Cancer Consortium. Pharmacogenomic agreement between two cancer cell line data 625 sets. Nature. 2015 Dec 3;528(7580):84-7. 
626 38. Bouhaddou M, DiStefano MS, Riesel EA, Carrasco E, Holzapfel HY, Jones DC,

627 Smith GR, Stern AD, Somani SS, Thompson TV, Birtwistle MR. Drug response 628 consistency in CCLE and CGP. Nature 2016;540:E9-E10.

629 39. Geeleher P, Gamazon ER, Seoighe C, Cox NJ, Huang RS. Consistency in large 630 pharmacogenomic studies. Nature 2016;540:E1-E2.

631 40. Mpindi JP, Yadav B, Östling P, Gautam P, Malani D, Murumägi A, Hirasawa A, 632 Kangaspeska S, Wennerberg K, Kallioniemi O, Aittokallio T. Consistency in drug 633 response profiling. Nature 2016;540:E5-E6.

634 41. Safikhani Z, El-Hachem N, Smirnov P, Freeman M, Goldenberg A, Birkbak NJ, 635 Beck AH, Aerts HJ, Quackenbush J, Haibe-Kains B. Safikhani et al. reply. Nature. 6362016 Nov 30;540(7631):E2-E4.

637 42. Safikhani Z, El-Hachem N, Smirnov P, Freeman M, Goldenberg A, Birkbak NJ, 638 Beck AH, Aerts HJ, Quackenbush J, Haibe-Kains B. Safikhani et al. reply. Nature. 6392016 Nov 30;540(7631):E6-E8.

640 43. Safikhani Z, El-Hachem N, Smirnov P, Freeman M, Goldenberg A, Birkbak NJ,

641 Beck AH, Aerts HJ, Quackenbush J, Haibe-Kains B. Safikhani et al. reply. Nature. 6422016 Nov 30;540(7631):E11-E12.

643 44. Safikhani Z, El-Hachem N, Quevedo R, Smirnov P, Goldenberg A, Juul Birkbak

644 N, Mason C, Hatzis C, Shi L, Aerts HJ, Quackenbush J, Haibe-Kains B. F1000Res. 6452016 May 9;5:825.

646 45. Safikhani Z, Smirnov P, Freeman M, El-Hachem N, She A, Rene Q, Goldenberg 647 A, Birkbak NJ, Hatzis C, Shi L, Beck AH, Aerts HJWL, Quackenbush J, Haibe-Kains 648 B. Revisiting inconsistency in large pharmacogenomic studies. Version 3. F1000Res. 6492016 Sep 16 [revised 2017 Jan 1];5:2333. 
650 46. Monks A, Scudiero DA, Johnson GS, Paull KD, Sausville EA. The NCI anti-

651 cancer drug screen: a smart screen to identify effectors of novel targets. Anticancer

652 Drug Des. 1997 Oct;12(7):533-41.

653 47. Reinhold WC, Varma S, Sousa F, Sunshine M, Abaan OD, Davis SR, Reinhold

654 SW, Kohn KW, Morris J, Meltzer PS, Doroshow JH, Pommier Y. NCI-60 whole 655 exome sequencing and pharmacological CellMiner analyses. PLoS One. 2014 Jul 656 17;9(7):e101670.

657 48. Reinhold WC, Sunshine M, Varma S, Doroshow JH, Pommier Y. Using CellMiner

6581.6 for Systems Pharmacology and Genomic Analysis of the NCl-60. Clin Cancer 659 Res. 2015 Sep 1;21(17):3841-52.

660 49. Chabner BA. NCl-60 Cell Line Screening: A Radical Departure in its Time. J Natl 661 Cancer Inst. 2016 Jan 11;108(5). pii: djv388.

662 50. Reinhold WC, Varma S, Sunshine M, Rajapakse V, Luna A, Kohn KW, 663 Stevenson H, Wang Y, Heyn H, Nogales V, Moran S, Goldstein DJ, Doroshow JH, 664 Meltzer PS, Esteller M, Pommier Y. The NCl-60 Methylome and Its Integration into 665 CellMiner. Cancer Res. 2017 Feb 1;77(3):601-612.

666 51. Reinhold WC, Varma S, Sunshine M, Elloumi F, Ofori-Atta K, Lee S, Trepel JB, 667 Meltzer PS, Doroshow JH, Pommier Y. RNA sequencing of the $\mathrm{NCl}-60$ : Integration 668 into CellMiner and CellMiner CDB. Cancer Res. 2019 May 21. pii: canres.2047.2018. 669 52. Kormanec J, Novakova R, Csolleiova D, Feckova L, Rezuchova B, Sevcikova B, 670 Homerova D. The antitumor antibiotic mithramycin: new advanced approaches in 671 modification and production. Appl Microbiol Biotechnol. 2020 Sep;104(18):77016727721. 
673 53. Gallego-Jara J, Lozano-Terol G, Sola-Martínez RA, Cánovas-Díaz M, de Diego

674 Puente T. A Compressive Review about Taxolß: History and Future Challenges.

675 Molecules. 2020 Dec 17;25(24):5986.

676 54. Rae JM, Creighton CJ, Meck JM, Haddad BR, Johnson MD. MDA-MB-435 cells

677 are derived from M14 melanoma cells--a loss for breast cancer, but a boon for 678 melanoma research. Breast Cancer Res Treat. 2007 Jul;104(1):13-9.

679 55. Ben-David U, Siranosian B, Ha G, Tang H, Oren Y, Hinohara K, Strathdee CA, 680 Dempster J, Lyons NJ, Burns R, Nag A, Kugener G, Cimini B, Tsvetkov P, Maruvka 681 YE, O'Rourke R, Garrity A, Tubelli AA, Bandopadhayay P, Tsherniak A, Vazquez F, 682 Wong B, Birger C, Ghandi M, Thorner AR, Bittker JA, Meyerson M, Getz G, 683 Beroukhim R, Golub TR. Genetic and transcriptional evolution alters cancer cell line 684 drug response. Nature. 2018 Aug;560(7718):325-330.

685 56. Noronha N, Ehx G, Meunier MC, Laverdure JP, Thériault C, Perreault C. Major 686 multilevel molecular divergence between THP-1 cells from different biorepositories. 687 Int J Cancer. 2020 Mar 12. doi: 10.1002/ijc.32967.

688 57. Voskuil JLA, Bandrowski A, Begley CG, Bradbury ARM, Chalmers AD, Gomes 689 AV, Hardcastle T, Lund-Johansen F, Plückthun A, Roncador G, Solache A, Taussig 690 MJ, Trimmer JS, Williams C, Goodman SL. The Antibody Society's antibody 691 validation webinar series. MAbs. 2020 Jan-Dec;12(1):1794421.

692 58. Hubert M, Vandervieren E. An adjusted boxplot for skewed distributions. 693 Computational Statistics and Data Analysis. 2008; 52(12): 5186-5201

694 59. Liu Y, Mi Y, Mueller T, Kreibich S, Williams EG, Van Drogen A, Borel C, Frank M, 695 Germain PL, Bludau I, Mehnert M, Seifert M, Emmenlauer M, Sorg I, Bezrukov F, 696 Bena FS, Zhou H, Dehio C, Testa G, Saez-Rodriguez J, Antonarakis SE, Hardt WD, 
697 Aebersold R. Multi-omic measurements of heterogeneity in HeLa cells across

698 laboratories. Nat Biotechnol. 2019 Mar;37(3):314-322.

699 60. Lorenzi PL, Reinhold WC, Varma S, Hutchinson AA, Pommier Y, Chanock SJ,

700 Weinstein JN. DNA fingerprinting of the NCl-60 cell line panel. Mol Cancer Ther.

7012009 Apr;8(4):713-24.

702 61. Eisenhauer EA, O'Dwyer PJ, Christian M, Humphrey JS. Phase I clinical trial 703 design in cancer drug development. J Clin Oncol. 2000 Feb;18(3):684-92.

704 62. Sachs JR, Mayawala K, Gadamsetty S, Kang SP, de Alwis DP. Optimal Dosing 705 for Targeted Therapies in Oncology: Drug Development Cases Leading by Example.

706 Clin Cancer Res. 2016 Mar 15;22(6):1318-24.

707 63. Mansinho A, Boni V, Miguel M, Calvo E. New designs in early clinical drug 708 development. Ann Oncol. 2019 Sep 1;30(9):1460-1465.

709 64. Corbaux P, El-Madani M, Tod M, Péron J, Maillet D, Lopez J, Freyer G, You B.

710 Clinical efficacy of the optimal biological dose in early-phase trials of anti-cancer

711 targeted therapies. Eur J Cancer. 2019 Oct;120:40-46.

712 65. Begley CG. Six red flags for suspect work. Nature 2013;497:433-4.

713 66. Ioannidis JP, Greenland S, Hlatky MA, Khoury MJ, Macleod MR, Moher D,

714 Schulz KF, Tibshirani R. Increasing value and reducing waste in research design,

715 conduct, and analysis. Lancet 2014;383:166-75.

716 67. Hatzis C, Bedard PL, Birkbak NJ, Beck AH, Aerts HJ, Stem DF, Shi L, Clarke R,

717 Quackenbush J, Haibe-Kains B. Enhancing reproducibility in cancer drug screening:

718 how do we move forward? Cancer Res. 2014 Aug 1;74(15):4016-23.

719 68. Freedman LP, Cockburn IM, Simcoe TS. The Economics of Reproducibility in 720 Preclinical Research. PLoS Biol. 2015;13:e1002165. 
721 69. Jarvis MF, Williams M. Irreproducibility in Preclinical Biomedical Research:

722 Perceptions, Uncertainties, and Knowledge Gaps. Trends Pharmacol Sci.

$7232016 ; 37: 290-302$.

724 70. Freedman LP, Venugopalan G, Wisman R. Reproducibility2020: Progress and 725 priorities. F1000Res. 2017;6:604.

726 71. Kaelin WG Jr. Publish houses of brick, not mansions of straw. Nature $727 \quad 2017 ; 545: 387$.

728 72. Karp NA, Speak AO, White JK, Adams DJ, Hrabé de Angelis M, Hérault Y, Mott 729 RF. Impact of temporal variation on design and analysis of mouse knockout 730 phenotyping studies. PLoS One. 2014 Oct 24;9(10):e111239.

731 73. Ding KF, Finlay D, Yin H, Hendricks WPD, Sereduk C, Kiefer J, Sekulic A, 732 LoRusso PM, Vuori K, Trent JM, Schork NJ. Analysis of variability in high throughput 733 screening data: applications to melanoma cell lines and drug responses. Oncotarget. 7342017 Apr 25;8(17):27786-27799.

735 74. Kafkafi N, Golani I, Jaljuli I, Morgan H, Sarig T, Würbel H, Yaacoby S, Benjamini 736 Y. Addressing reproducibility in single-laboratory phenotyping experiments. Nat 737 Methods. 2017 Apr 27;14(5):462-464.

738 75. Karp NA. Reproducible preclinical research-ls embracing variability the answer? 739 PLoS Biol. 2018 Mar 5;16(3):e2005413.

740 76. Milcu A, Puga-Freitas R, Ellison AM, Blouin M, Scheu S, Freschet GT, Rose L, 741 Barot S, Cesarz S, Eisenhauer N, Girin T, Assandri D, Bonkowski M, Buchmann N, 742 Butenschoen O, Devidal S, Gleixner G, Gessler A, Gigon A, Greiner A, Grignani C, 743 Hansart A, Kayler Z, Lange M, Lata JC, Le Galliard JF, Lukac M, Mannerheim N, 744 Müller MEH, Pando A, Rotter P, Scherer-Lorenzen M, Seyhun R, Urban-Mead K, 
745 Weigelt A, Zavattaro L, Roy J. Genotypic variability enhances the reproducibility of

746 an ecological study. Nat Ecol Evol. 2018 Feb;2(2):279-287.

747 77. Voelkl B, Vogt L, Sena ES, Würbel H. Reproducibility of preclinical animal

748 research improves with heterogeneity of study samples. PLoS Biol. 2018 Feb

749 22;16(2):e2003693.

750 78. Bodden C, von Kortzfleisch VT, Karwinkel F, Kaiser S, Sachser N, Richter SH.

751 Heterogenising study samples across testing time improves reproducibility of

752 behavioural data. Sci Rep. 2019 Jun 3;9(1):8247.

753 79. von Kortzfleisch VT, Karp NA, Palme R, Kaiser S, Sachser N, Richter SH.

754 Improving reproducibility in animal research by splitting the study population into

755 several 'mini-experiments'. Sci Rep. 2020 Oct 6;10(1):16579.

756 80. Shankavaram UT, Varma S, Kane D, Sunshine M, Chary KK, Reinhold WC,

757 Pommier Y, Weinstein JN. CellMiner: a relational database and query tool for the

758 NCI-60 cancer cell lines. BMC Genomics. 2009 Jun 23;10:277. 